\title{
ROOFTOP RAINWATER HARVESTING SYSTEM AND IN-LINE TREATMENT
}

\author{
Ranjeet Sable $^{1}$, Mayur Shinde ${ }^{2}$, Rohit Deshmukh ${ }^{3}$, Kirti Zare ${ }^{4}$, Sainand Khot ${ }^{5}$ \\ 1,2,3,4,5 Assistant Professor, Dr. D. Y. Patil Institute of Engineering, Management \& Research, Pune in Savitribai Phule \\ Pune University, India
}

\begin{abstract}
Water is one of the basic needs of living beings. Generally water is available on the earth in the form of salt water and fresh water. Fresh water available is in the form of frozen and unfrozen state. Unfrozen fresh water is found mainly as groundwater and surface water which only can be directly used. As the human population increases, water demand increases and the water scarcity problem arises. There are many remedial measures on the water scarcity which can be applied on each scale. The measures such as recycling of treated wastewater, conservation through minimizing water consumption and rainwater harvesting will help to reduce load on water demand.
\end{abstract}

Keywords: Precipitations, Rainfall, Catchment Area, Flow Rate, Turbidity, Treatment Unit. $* * *$

\section{INTRODUCTION}

Rainwater harvesting is an old and cost effective practice that is being adopted by many nations as a viable decentralized water source. Individual Rainwater Harvesting Systems (RHS) are one of the many tools to meet the growing water demand. Rainwater harvesting can be defined as a method for inducing, collecting, storing and conserving local surface runoff. Rainwater harvesting is the accumulation and deposition of rainwater for reuse before it reaches the aquifer. The simple definition of rainwater harvesting can be, "catch water where it falls." Its applications include water for garden, livestock, irrigation, etc. In many places the water collected is just redirected to a deep pit with percolation. There are mainly two types of rainwater harvesting as ,surface runoff harvesting" and "Rooftop Rainwater Harvesting System (RRHS) ${ }^{e c}$.

Surface runoff is the water flow that occurs when the soil is infiltrated to full capacity and excess water from rain or other sources flows over the land, surface runoff can be generated either by rainfall or by the melting of snow, or glaciers. There are many ways to harvest surface runoff. This runoff could be caught and used for recharging aquifers by adopting appropriate methods. It reduces the rate of power consumption for pumping of groundwater.

\section{MATERIALS AND METHODS}

Materials and Methods adopted for study are discussed in sub-sections like various aspects of determination of volume of first flush and package in-line treatment system.

\subsection{Experimental Setup}

\section{First Flush Quantification}

The grid of perforated PVC pipes was laid on the rooftop of Environmental Engineering laboratory building of WCE, Sangli to spray water simulating rain event. The material of the roof is corrugated AC sheet. The grid was fixed in total area of $10 \mathrm{~m} 2$ which was divided into two parts viz. „Area $1^{\text {ec }}$ and „Area $2^{\text {ec }}$. Ten vertical pipes were connected at a distance of every $0.5 \mathrm{~m}$ to a single horizontal pipe which was placed at the downside of the grid. The pump of half HP was installed to spray the water on the rooftop through a grid.

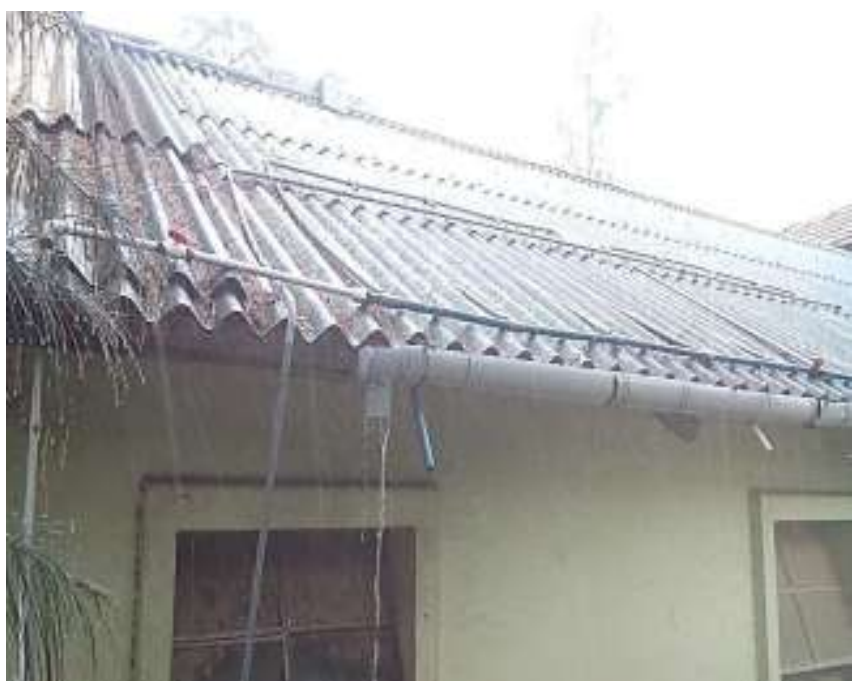

Fig. 1 (a) Collection of Rainwater 


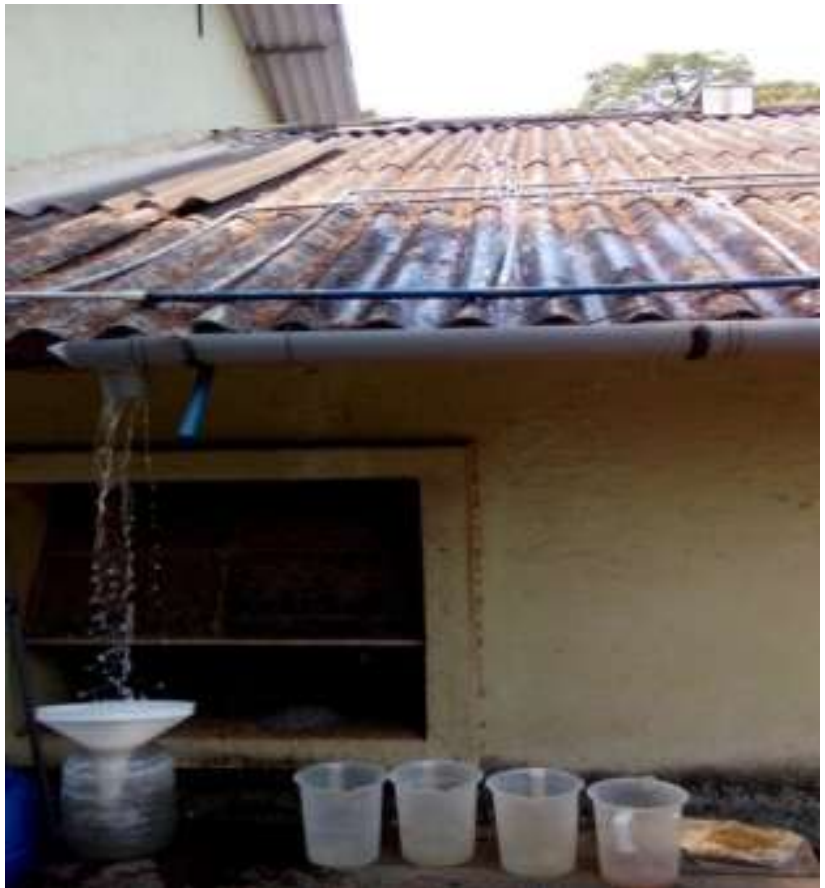

Fig. 1 (b) Variation in turbidity

\subsection{Quantification of Volume of First Flush}

The turbidity was measured of rooftop sprayed water which was collected in series in containers. Fig. (a) Shows the results of all the experiments carried out for $2.5 \mathrm{~m} 2$ area. Fig. (b) represents the variation in turbidity with throughput volume for dry periods of 2, 6 and 10 days respectively. All the experiments were conducted for various flow rates corresponding to rainfall intensities of 10,30 and $60 \mathrm{~mm} / \mathrm{hr}$. The initial turbidity of sprayed water was always measured and it was found to be less than 2 or 3 NTU.

\section{DEVELOPMENT OF PACKAGE IN-LINE SYSTEM}

Design, development and performance evaluation of package in-line treatment system is an important objective of this study. Package in-line treatment system is a treatment system to treat the rooftop harvested rainwater. Important factors to be considered in designing and developing the package in-line treatment system are roof material and area from which rainwater to be harvest and rainfall intensity. A basic water treatment process was applied for this system. The treatment system was installed at the back side of laboratory of Environmental Engineering department of WCE, Sangli. The roof area from which the rooftop rainwater comes to the system was $245 \mathrm{~m} 2$. Average hourly rainfall in the Sangli region is $5 \mathrm{~mm} / \mathrm{hr}$. following are the treatment units of package in-line treatment system:

1. First flush diverter

2. Coagulation unit (adding and mixing)

3. Clarifier unit

4. Tube settler (horizontal and inclined)

5. Back flush unit

The treatment system developed is shown schematically and with photographic view.

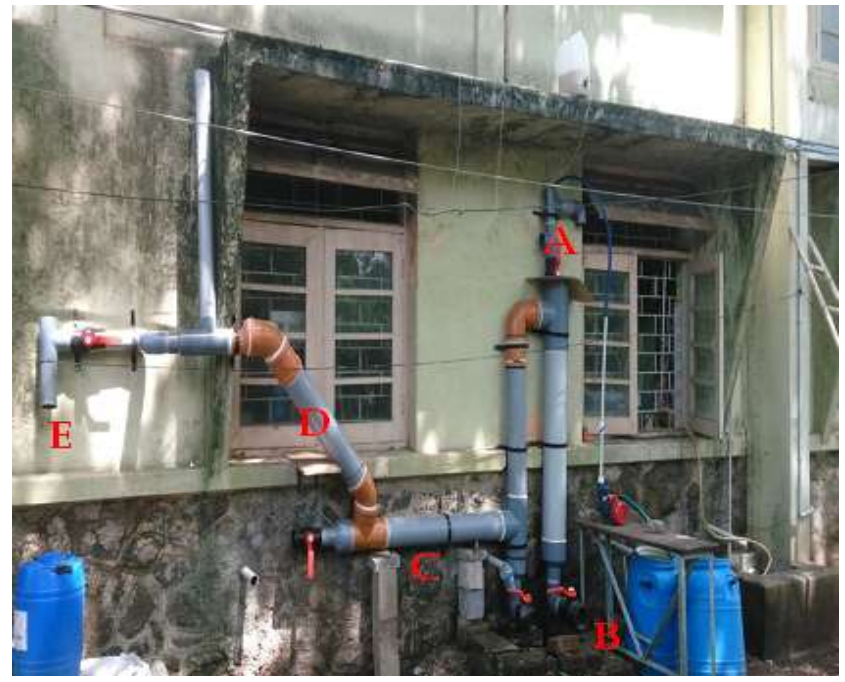

A - Inlet from roof top + Coagulation B - Drain Valve

C- Horizontal Tube settler+ control valve D - Inclined Tube Settler E-Discharge Valve

Fig. 1 (c) Experimental Set-up

\section{CALCULATiON}

Table 1: Details of run in which average flow rate and inlet turbidity was 3.1 lit./min. and 20 NTU respectively.

\begin{tabular}{|l|l|l|l|l|}
\hline $\begin{array}{l}\text { Sr } \\
\text { no }\end{array}$ & $\begin{array}{l}\text { Time } \\
(\mathrm{min})\end{array}$ & $\begin{array}{l}\text { Inlet turbidity } \\
(\mathrm{NTU})\end{array}$ & $\begin{array}{l}\text { Flow rate } \\
\text { (lit./min.) }\end{array}$ & $\begin{array}{l}\text { Outlet turbidity } \\
\text { (NTU) }\end{array}$ \\
\hline 1 & 35 & 21.4 & 3.1 & 9.0 \\
\hline 2 & 45 & 21.7 & 3.6 & 8.7 \\
\hline 3 & 55 & 22.3 & 2.9 & 8.8 \\
\hline 4 & 65 & 21.6 & 3.3 & 9.1 \\
\hline
\end{tabular}

Table 2: Details of run in which average flow rate and inlet turbidity was $4.5 \mathrm{lit}$ / $\mathrm{min}$. and 20 NTU respectively

\begin{tabular}{|l|l|l|l|l|}
\hline $\begin{array}{l}\text { Sr } \\
\text { no }\end{array}$ & $\begin{array}{l}\text { Time } \\
(\mathrm{min})\end{array}$ & $\begin{array}{l}\text { Inlet turbidity } \\
(\mathrm{NTU})\end{array}$ & $\begin{array}{l}\text { Flow rate } \\
\text { (lit./min.) }\end{array}$ & $\begin{array}{l}\text { Outlet turbidity } \\
\text { (NTU) }\end{array}$ \\
\hline 1 & 25 & 25.6 & 4.5 & 11.3 \\
\hline 2 & 35 & 29.3 & 4.8 & 10.2 \\
\hline 3 & 45 & 23.0 & 4.4 & 8.8 \\
\hline 4 & 55 & 24.9 & 4.2 & 11.1 \\
\hline
\end{tabular}

\section{CONCLUSION}

\subsection{Quantization of Volume of First Flush}

1. As per literature, the theoretical volume of first flush is depends only upon roof area. But as per the study carried out, it is observed that actual volume of first flush depends upon roof area, rainfall intensity and dry periods.

2. Target turbidity along with roof material and surrounding conditions are also plays an important role in deciding volume of first flush.

3. For a specific roof area, volume of first flush increases with increase in dry days.

4. For a specific roof area, volume of first flush decreases with increase in rainfall intensity.

5. If all the factors are considered, volume of first flush will be more than two times the theoretical volume of first flush. But this will helps in improving the quality of harvested rainwater. 


\subsection{Package In-Line Treatment}

1. Package in-line treatment system is helps in improving the quality of rooftop harvested rainwater.

2. It is observed that the removal efficiency of turbidity decreases with increase in flow rate. Highest removal efficiency i.e. about 67 to $75 \%$ was observed for flow rate 3.2 lit./min., while it was decreased up to 16 to $32 \%$ for 14lit./min., flow rate.

3. Addition of coagulant (aluminum sulphate) helps in increasing the removal efficiency by about 12 to $15 \%$.

\section{REFERENCES}

[1] Abdulla F and Al-Shareef A., (2008), "Roof rainwater harvesting systems for household water supply in Jordan" Desalination, Volume 243, Issues 1-3, July 2009, Pages 195-207.

[2] Adler I., Hudson K. A. and Campos L.C. (2011), "Converting rain into drinking water: quality issues and technological advances", Journal of Water Science \& Technology: Water Supply, Vol. 11, No 6, 659-667.

[3] Amin M. T. and Han M. Y., (2011) "Improvement of solar based rainwater disinfection by using lemon and vinegar as catalysts", ", Desalination, Volume 276, Issues 1-3, 2 August 2011, Pages 416-424.

[4] Aphale A. A. (2013), "Studies on Quality and Treatment of Rooftop Harvested Rainwater in Sangli and Kupwad Area", submitted for M. Tech. dissertation to Dept. of Civil-Environmental Engg., Walchand College of Engineering, Sangli.

[5] Brett Martinson D and Terry Thomas (2005), "Quantifying the first flush phenomenon", submitted for M. Sc. dissertation to Development Technology Unit, School of Engineering, University of Warwick

[6] Chang M., McBroom M. W. and Beasley R. S. (2004), "Roofing as a source of nonpoint water pollution", Journal of Environmental Management, vol. 73.

[7] . Doyle K. C. (2006), "sizing the first flush and its effect on the storage - reliability - yield behavior of rainwater harvesting in Rwanda", submitted for M. Sc. dissertation to Massachusetts Institute of Technology.

[8] Forster J. (1999), "Variability of roof runoff quality", Water Science and Technology, vol. 39(5), 137-144.

[9] Helmreich B. and Horn H. (2008), "Opportunities in rainwater harvesting", Elsevier Desalination 251 (2010) $118-124$. 